\title{
Effect of Gestational Diabetes on Neuronal Cells in Rat Cerebellum in Early Postnatal Life
}

\author{
Efecto de la Diabetes Gestacional sobre las Células Neuronales \\ del Cerebelo de Ratas en el Período Postnatal
}

Elahe Mirarab Razi*; Soraya Ghafari**; Vida Hojati* \& Mohammad Jafar Golalipour ${ }^{* * *}$

RAZI, E. M.; GHAFARI, S.; HOJATI, V. \& GOLALIPOUR, M. J. Effect of Gestational diabetes on neuronal cells in rat cerebellum in early postnatal life. Int. J. Morphol., 32(2):420-425, 2014.

SUMMARY: Previous study has shown the adverse effects of gestational diabetes on hippocampal neuronal density in animal model. This study was conducted to determine the effect of gestational diabetes on rat cerebellum in early postnatal life. In this experimental study, 10 dams randomly allocated into control and diabetic groups on day 1 of gestation. Five dams in diabetic group were administered $40 \mathrm{mg} / \mathrm{kg} / \mathrm{BW}$ (intraperitoneally) of streptozotocin and control animals received normal saline. Six offspring of each gestational diabetes mellitus and controls were randomly selected at day 7 of postnatal life. Offspring were sacrificed and coronal sections were taken from the cerebellum and stained with cresyl violet. The number of Purkinje and granular cells and thickness of layers of cerebellum were evaluated by quantitative computer-assisted morphometric method. The Purkinje cells density at apex and depth of cerebellar lobules in the experimental group $(14.40 \pm 0.7,14.86 \pm 0.6)$ significantly reduced in comparison with the control group $(16.72 \pm 0.3,17.85 \pm 0.7)$ $(\mathrm{P}<0.05)$. The granular cell density at apex and depth of cerebellar lobules in the experimental group $(23.94 \pm 0.6,22.81 \pm 0.5)$ significantly reduced in comparison with the control group $(29.20 \pm 0.8,28.1 \pm 0.8)(\mathrm{P}<0.05)$. The thickness of the Purkinje and internal granular and molecular layers at apex and depth of cerebellar cortex significantly reduced in diabetics group compared to controls $(\mathrm{P}<0.05)$. This study revealed that gestational diabetes induces loss of number and size of the Purkinje cells and the granular cells and reduction of thickness of the Purkinje and internal granular layer of the cerebellar cortex in neonatal mice.

KEY WORDS: Gestational diabetes; Cerebellum, Purkinje cell; Granular cell; Rat.

\section{INTRODUCTION}

Diabetes mellitus is one of the most common serious metabolic disorders characterized by hyperglycemia, altered metabolism of lipids, carbohydrates and proteins (Lebed et al., 2008).

Type I or insulin dependent, type II or insulin independent and gestational diabetes are three general classifications of diabetes mellitus. Diabetes mellitus is associated with vascular disorder, retinopathy, cardiomyopathy, altered immune functions, changes in the intestinal function, peripheral neuropathy, and dysfunctions of the central nervous system in both human and animal models of the disease (Biessels et al., 2002).

Dysfunctions of the central nervous system include the abnormal expression of hypothalamic neuropeptidase, hippocampal astrogliosis and decreased hippocampal synaptic plasticity (Saravia et al., 2002; Kamal et al., 1999). Diabetic patients are prone to moderate alterations in memory and learning (Schoenle et al., 2002). Evidence for brain disturbances were reported in hypothalamus, cerebral cortex and hippocampus of streptozotocin (STZ)-induced diabetic rats (Jackson-Guilford et al., 2000).

Gestational diabetes mellitus (GDM) defined as impaired glucose tolerance affects approximately $4 \%$ of all pregnant women who have never before had diabetes, but who do have high blood glucose levels during pregnancy and involves an interaction between diabetic susceptibility genes and diabetogenic effects of pregnancy.

The cerebellum has long been recognized as the primary center of motor coordination in the central nervous system (Gardoni et al., 2002; Ahmadpour \& Haghir, 2011).

\footnotetext{
" Department of Biology, Damghan Branch, Islamic Azad University, Damghan, Iran,

** Department of Anatomical Sciences, Golestan University of Medical Sciences, Gorgan, Iran.

*** Professor, Gorgan Congenital Malformations Research Center, Department of Anatomical Sciences, Golestan University of Medical Sciences, Gorgan, Iran.
} 
Recent studies in humans have also implicated the cerebellum in cognitive processing and sensory discrimination in medical conditions as diverse as pervasive developmental disorders, autism, and cerebellar vascular injuries (Arroba et al., 2005; Anitha et al., 2006).

Disorder and disagreement in cerebellar structure was reported due to type 1 diabetes mellitus (Arroba et al.). Also, Hernandez-Fonseca et al. (2009) study has shown that STZ induced diabetes increased apoptosis in pyramidal neurons in cortex and cerebellar Purkinje cells in adult rats.

Some studies have shown the adverse effects of maternal diabetes on reduction of hippocampus neuronal density (Biessels et al.) and decrease of neuron and thickness of cortex and white matter of cerebellum in neonatal rats (Min et al., 2005). Also, our previous study has shown that gestational diabetes induced neuronal cell loss in CA1 and CA3 subfields of rat hippocampus in early postnatal life (Golalipour et al., 2012).

Follow-up studies concerning the adverse effects of diabetic pregnancy on the developing brain have revealed neurobehavioral deficits in both sensory-cognitive and psychomotor functions including altered auditory recognition memory processing at birth, reduce visual and memory performance at 8 and 12 months and inferior performance in elementary school children (Siddappa et al., 2004; DeBoer et al., 2005). While motor delay may be a sign of mild, nonspecific brain damage, the abnormalities in memory processing suggest alterations in hippocampal development and function (Nelson et al., 2000).

Although there are several studies regarding the adverse effects of type I and type II diabetes mellitus on CNS including hippocampus, hypothalamus, cerebellum and cerebrum (Beauquis et al., 2006; Ahmadpour \& Haghir) but there is no study about the effect of gestational diabetes on neuronal development of cerebellum which are important in coordination and balance of muscles and voluntary and involuntary movements. Therefore, this experimental study was designed to assess the effect of gestational diabetes on neuronal density and thickness of cortical layers of cerebellum in the postnatal 7 day of Wistar rats.

\section{MATERIAL AND METHOD}

This experimental study was performed at the Gorgan Faculty of Medicine, Golestan University of Medical Sciences, Gorgan, Iran. Guidelines on the care and use of laboratory animals and approval of the ethics committee of
Golestan University of Medical Sciences were obtained before study.

Experimental animals. Wistar rats, weighing 180-220 grams (12 weeks old) were used in this study. The animals were maintained in a climate-controlled room under a 12hour alternating light/dark cycle, $20^{\circ} \mathrm{C}$ to $25^{\circ} \mathrm{C}$ temperature, and $50 \%$ to $55 \%$ relative humidity. Dry food pellets and water were provided ad libitum.

Drug. Streptozotocin (STZ) (Sigma, St. Louis, MO, USA) dissolved in sterile saline solution (0.85\%) to give $40 \mathrm{mg} /$ $\mathrm{kg}$ dose intraperitoneally injected to female rats.

Animal groups and treatment. After 2 weeks of acclimation to the diet and the environment, female Wistar rats were placed with a proven breeder male overnight for breeding. Vaginal smears were done the next morning to check for the presence of sperm. Once sperm was detected that day was assigned as gestational day 1 (GD). On day 1 of gestation, pregnant females randomly divided into two control and diabetic groups.

Five female rats in diabetic group receiving $40 \mathrm{mg} /$ $\mathrm{kg} /$ body weight of streptozotocin (STZ) and control groups (five rats) receiving an equivalent volume normal saline injection intraperitoneally (IP). Blood was sampled from the tail at 1 week after STZ injection. The dams with blood glucose level 120-250 mg/dl known as gestational diabetes (GDM). The pregnancy of dams was terminated physiologically.

Totally six offspring of gestational diabetic mothers and control mothers at the day 7 (P7) were randomly selected and were sacrificed. For light microscope preparations cerebellum was fixed in $10 \%$ neutral-buffered formalin for histological procedure. The coronal sections (6 micrometer) serially collected from bregma $-9.96 \mathrm{~mm}$ to $-11.88 \mathrm{~mm}$ of cerebellum. The sections were stained with cresyl violet.

Blood glucose measurements. Blood glucose level of mothers (before mating and after STZ injection) and offspring was obtained via tail vein and was estimated with a glucometer (ACCU-CHEK ${ }^{\circledR}$ Active Glucometer, Roche Diagnostics, Mannheim, Germany).

Morphometric techniques. In each sample, ten similar sections of anterior lobes of cerebellum were selected and images of five separate fields in the apex of cerebellar lobules and five separate fields in the depth of cerebellar lobules were captured by Olympus BX 51 microscope and DP12 digital camera attached to OLYSIA autobioreport software (Olympus Optical, Co. LTD, Tokyo, Japan). 
The morphometric analysis of cerebellum included densities of Purkinje cell (the number of Purkinje cells/ $10000 \mu \mathrm{m}^{2}$ area of the Purkinje cell layer), diameter and area of the Purkinje cells were measured from high magnification (100x objectives). Also densities of granular cells (the number of the granular cells/ 10000 $\mu \mathrm{m}^{2}$ area of granular cell layer) and the thickness of cerebellar cortex included thickness of external granular cell layer (EGL), molecular layer (ML), Purkinje cell layer (PCL) and internal granular cell layer (IGL) were measured from low magnification (40x objective) (Fig. 1).

Statistical analysis. Morphometric data is expressed as the Mean \pm SEM and analyzed by the Student's " $t$ " test using SPSS 16.5 software. $\mathrm{P}<0.05$ was considered significant.

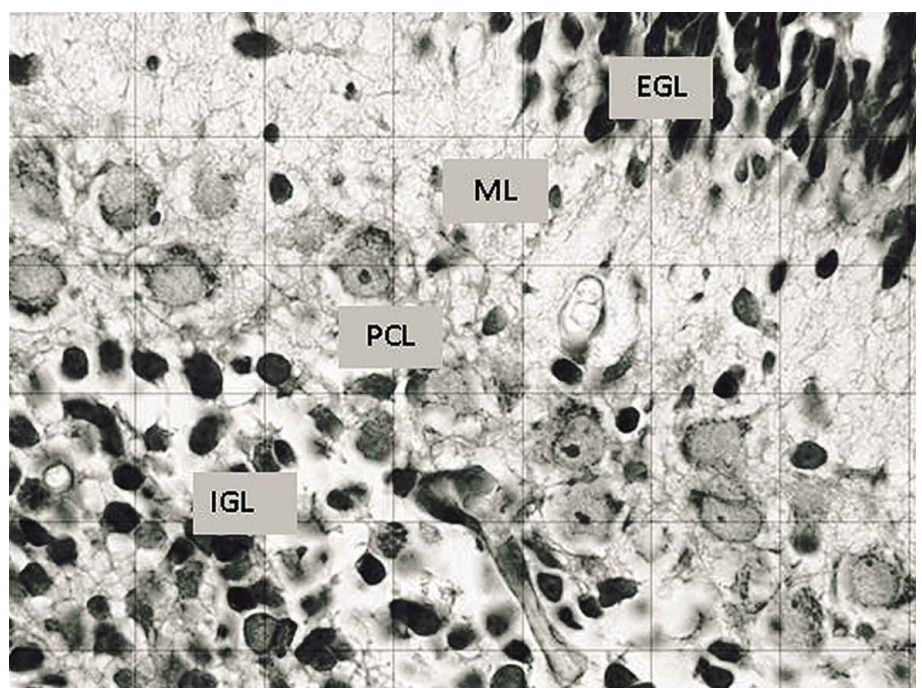

Fig. 1. Coronal section of cerebellum cortex postnatal day 7 (P7) mice in control group. Coronal section stained with cresyl violet. EGL: external granule cell layer, ML: molecular layer, PCL: Purkinje cell layer, IGL: inner granule cell layer (100X).

\section{RESULTS}

The morphometric findings are depicted in Tables I and II.
The numbers of PCs in apex of cerebellar lobules decreased from $16.7 \pm 0.3$ cells in control group to $14.40 \pm 0.7$ cells in $10000 \mathrm{~mm}^{2}$ area of pc layer in GD group $(\mathrm{P}<0.01)$. Also, the numbers of $\mathrm{PCs}$ in depth of cerebellum decreased from $17.85 \pm 0.7$ cells in control group to $14.86 \pm 0.6$ cells in $10000 \mathrm{~mm}^{2}$ area of pc layer in GD group $(\mathrm{P}<0.006)$.

The results showed that the diameter of the Purkinje cells in apex and depth region of cerebellar lobules GD group reduced in comparison with the controls $(\mathrm{P}<0.006)$. In addition, the mean area of the Purkinje cells in the control group was larger $\left(52.78 \pm 1.5 \mathrm{~mm}^{2}\right)$ than treated group $(44.72 \pm 0.89$ $\mathrm{mm}^{2}$ ) (Table I).

The numbers of granular cells in apex of cerebellar lobules decreased from $29.20 \pm 0.9$ cells in control group to $23.97 \pm 0.6$ cells in $10000 \mathrm{~mm}^{2}$ area of granular cell layer in GD group $(\mathrm{P}<0.001)$. Also, the numbers of granular cells in depth of cerebellar lobules decreased from $28 \pm 1.2$ cells in control group to $22.7 \pm 0.7$ cells in $10000 \mathrm{~mm}^{2}$ area of granular cell layer in $\mathrm{P} 7 \mathrm{GD}$ group $(\mathrm{P}<0.001)$ (Table I).

The mean thickness of the cerebellar cortex layers in apex and depth of cerebellum had decreased in the gestational diabetic group in comparison with the control group $(\mathrm{P}<0.05)$.

The thickness of the Purkinje cell layer in gestational diabetes offspring significantly reduced from $44.87 \pm 3.1 \mu \mathrm{m}$ to $36.15 \pm 1.6 \mu \mathrm{m}$ in controls at apex section, and significantly reduced from $45.24 \pm 2.4 \mu \mathrm{m}$ to $37.61 \pm 0.9 \mu \mathrm{m}$ in controls at depth section of cerebellar lobules.

Reduction of the thickness of EGL and ML and internal granular cell layer (IGL) in case group than control group depicted in Table II.

Table I. The quantitative characteristics of the Purkinje cells of cerebellum in postnatal day 7 (P7) of gestational diabetes mellitus (GDM) and control mothers in Wistar rat.

\begin{tabular}{llccc}
\hline Characteristics & Control (P7) & GD (P7) & P-value \\
\hline Apex & PC density $\left(\mathrm{PC}\right.$ Number $/ 10000 \mu \mathrm{m}^{2}$ area of PCL) & $16.7 \pm 0.3$ & $14.40 \pm 0.7$ & 0.01 \\
& Area of PCs $\left(\mu \mathrm{m}^{2}\right)$ & $46.33 \pm 2.2$ & $36.18 \pm 2.1$ & 0.01 \\
& Diameter of PCs $(\mu \mathrm{m})$ & $9.14 \pm 0.32$ & $8.22 \pm 0.15$ & 0.006 \\
& GC density at apex $\left(\mathrm{GC}\right.$ Number $/ 10000 \mu \mathrm{m}^{2}$ rea of GCL) & $29.20 \pm 0.9$ & $23.97 \pm 0.6$ & 0.001 \\
\multirow{5}{*}{ Depth } & $17.85 \pm 0.7$ & $14.86 \pm 0.6$ & 0.006 \\
& PC density $\left(\mathrm{PC}\right.$ Number $/ 10000 \mu \mathrm{m}^{2}$ area of PCL) & $70.20 \pm 1.4$ & $61.15 \pm 2.8$ & 0.02 \\
& Area of PCs $\left(\mu \mathrm{m}^{2}\right)$ & $9.58 \pm 0.4$ & $8.63 \pm 0.3$ & 0.006 \\
& Diameter of PCs $(\mu \mathrm{m})$ & $28 \pm 1.2$ & $22.7 \pm 0.7$ & 0.001 \\
\hline
\end{tabular}

Results are expressed as Mean \pm SE of the mean, $\mathrm{P}<0.05$ versus control $(\mathrm{n}=6)$. 
Table II. The thickness of the various layers of cerebellar cortex $(\mathrm{mm})$ in postnatal day 7 (P7) of gestational diabetes (GDM) and control mothers in Wistar rat.

\begin{tabular}{llccc}
\hline Layer & & Control (P7) & GD (P7) & P-value \\
\hline Apex & EGL & $86.35 \pm 2.5$ & $74.06 \pm 3.1$ & 0.007 \\
& ML & $42.67 \pm 2.2$ & $40.92 \pm 2.1$ & $>0.05$ \\
& PCL & $44.87 \pm 3.1$ & $36.15 \pm 1.6$ & 0.01 \\
& IGL & $207.22 \pm 5.2$ & $189.38 \pm 3.3$ & 0.01 \\
Depth & EGL & $100.04 \pm 3.5$ & $88.78 \pm 1.6$ & 0.03 \\
& ML & $49.56 \pm 1.9$ & $46.46 \pm 1.8$ & $>0.05$ \\
& PCL & $45.24 \pm 2.4$ & $37.61 \pm 0.9$ & 0.007 \\
& IGL & $182.78 \pm 5.2$ & $162.96 \pm 4.3$ & 0.04 \\
\hline
\end{tabular}

$\mathrm{EGL}=$ external granule cell layer, $\mathrm{ML}=$ molecular layer, $\mathrm{PCL}=$ Purkinje cell layer, $\mathrm{IGL}=$ inner granule cell layer. Results are expressed as Mean $\pm \mathrm{SE}$ of the mean, $\mathrm{P}<0.05$ versus control $(n=6)$.

\section{DISCUSSION}

The present study demonstrated that gestational diabetes produces a significant reduction in the density of the Purkinje and Granular cells and several layers of cerebellum in the postnatal day 7 of Wistar rats.

Several animal model studies have shown that mothers with type 1 and 2 diabetes mellitus born offspring with low neuronal density in hippocampus (Beauquis et al.), granule layer of dentate gyrus (Gardoni et al.; Ahmadpour \& Haghir) and cerebrum (Khaksar et al., 2010).

Previous studies have shown reduced neuronal density in animals with type 1 and 2 diabetes mellitus (Beauquis et al.; Ahmadpour \& Haghir). Also, HernandezFonseca et al., study reported the effect of diabetes I on cellular structure of cerebellum. This study has shown that STZ induced diabetes increased apoptosis in pyramidal neurons in cortex and cerebellar Purkinje cells in adult rats.

Indeed, Khaksar et al., study showed the adverse effects of maternal diabetes on reduction of neuron and thickness of cortex and white matter of cerebellum in neonatal rats.

In spite of several studies regarding the effects of in diabetes I and II on CNS including cerebellum, there is no investigation about the effect of gestational diabetes on cerebellar neurons in offspring.

Our animal model study demonstrated that gestational diabetes similar to type I and II diabetes mellitus, has a neurotoxic effect on cerebellum of offspring. Neurotoxic effect of gestational diabetes established as significant reduction in the cerebellar Purkinje and granular cells in the postnatal 7 day of Wistar rats.
The reduction of Purkinje cell density of cerebellum can be due to program cell death or block of neurogenesis in CNS (Kamal et al.; Hernández-Fonseca et al.). Hyperglycemia could induce cellular death by enhancing tissue acidosis (DeBoer et al.).

Diabetes mellitus, regardless of its type, is associated with hyperglycemia. Several possible mechanisms are explained in reference to cerebral alterations including neuronal loss of cerebellum due to hyperglycemia. Hyperglycemia induces multiple cellular responses. These can be considered to be neurologically passive or active cellular responses (Klein \& Waxman, 2003).

Diabetes mellitus is a chronic endogenous stressor that is associated with increased oxidative stress in central nervous system in particular hippocampus (Grillo et al., 2005). The polyol pathway is activated during hyperglycemia and leads to consumption of NADPH and depletion of glutathione, which lower the threshold for intracellular oxidative injury (Klein \& Waxman).

CNS complications of diabetes mellitus could be mediated through excessive free radicals generation (Okouchi et al., 2005). These radicals contribute to increase neuronal death by oxidizing proteins, damaging DNA, and inducing the lipoperoxidation of cellular membranes (Hawkins \& Davies, 2001).

Hernandez-Fonseca et al., study showed that cerebral cortex and cerebellum presented morphologic alterations suggesting swelling of the brain due to hyperglycemia.

Hyperglycemia may cause brain acidosis and dehydration, both involved in diminished cerebral blood flow 
and ischemia (DeBoer et al.). Ischemia-related edema involves stimulation of brain $\mathrm{Na}-\mathrm{K}-\mathrm{Cl}$ co-transporter system facilitating edema formation and swelling of endothelial cells (Gardoni et al.).

Also, in other passive cellular responses increased formation of advanced glycosylation end-products damages endothelial cells, therefore it is contributed to vascular damage indeed, during hyperglycemia. Diacylglycerol activation of protein kinase $\mathrm{C}$ has negative effects on cerebral blood flow and vascular permeability (Klein \& Waxman). Indeed, other possible mechanism in the cause of program cell deaths in diabetes mellitus can be due to decreased insulin or insulin-like growth factor signaling, or an increase in cytokines such as TNFa.

Moreover, insulin-like growth factor has a neuroprotective anti-apoptotic effect and down regulation of expression of insulin-like growth factor and its receptor in diabetes might also be expected to lead to neuronal loss (Li et al., 2002).

Furthermore, several studies have shown that the damage to both presynaptic and postsynaptic structures in the hippocampus in diabetes from hyperglycemia induced alterations in the handling and homoeostasis of intracellular calcium concentrations (Candy \& Szatkowski, 2000). Also, up regulated GLUT-3 transporters as one of the compensatory response aimed at increasing neuronal glucose uptake and use, is low in diabetes (Okouchi et al.).

Down regulation of nitric oxide synthase (NOS), mRNA and protein concentrations are the main factors in active response of cells due to hyperglycemia. These changes are shown in hippocampal neurons (Reagan \& McEwen, 2002).

In conclusion, this study showed the uncontrolled gestational diabetes induces neurotoxic effects on the Purkinje neurons in offspring. Further studies are required for exploring the exact mechanism of CNS complications of gestational diabetes mellitus.

\section{ACKNOWLEDGEMENTS}

We thank the Deputy Research of Golestan University of Medical Sciences for financial support of this research (Grant number: 1357).

RAZI, E. M.; GHAFARI, S.; HOJATI, V. \& GOLALIPOUR, M. J. Efecto de la diabetes gestacional sobre las células neuronales del cerebelo de ratas en el período postnatal. $n$ t. J. Morphol., 32(2):420-425, 2014.

RESUMEN: Estudios previos han demostrado los efectos adversos de la diabetes gestacional sobre la densidad neuronal del hipocampo en modelos animales. Este estudio se realizó para determinar el efecto de la diabetes gestacional en el cerebelo de ratas durante la edad temprana postnatal. Fueron asignadas 10 ratas hembras al azar en grupos control y diabético en el primer día de gestación. Cinco en el grupo diabético recibieron una dosis de $40 \mathrm{mg} / \mathrm{kg} /$ Peso corporal de estreptozotocina (intraperitoneal) y los control una solución salina normal. Seis crías de cada una de las hembras del grupo diabetes mellitus gestacional y del grupo controles fueron seleccionados al azar el día 7 de vida postnatal. Fueron sacrificadas y se obtuvieron secciones coronales desde el cerebelo que fueron teñidas con violeta de cresilo. El número de células granulares de Purkinje y espesor de las capas de cerebelo fueron evaluadas por método morfométrico y ordenador cuantitativo. La densidad de células de Purkinje en el ápice y profundidad de los lóbulos del cerebelo en el grupo experimental $(14,40 \pm 0,7$ y $14,86 \pm 0,6)$ se redujeron significativamente en comparación con el grupo control $(16,72 \pm 0,3$ y $17,85 \pm 0,7)(\mathrm{P}<0,05)$. La densidad de células granulares en el ápice y profundidad de los lóbulos del cerebelo en el grupo experimental $(23,94 \pm 0,6$ y $22,81 \pm 0,5)$ se redujo significativamente en comparación con el grupo control $(29,20 \pm 0,8$ y $28,1 \pm 0,8)(P<0,05)$. En el espesor de células Purkinje, las capas moleculares y granulares internas en el ápice y profundidad de la corteza del cerebelo, se observó una reducción significativa en el grupo diabéticos en comparación con los controles $(\mathrm{P}<0,05)$. Se observó que la diabetes gestacional induce la pérdida del número y tamaño de las células Purkinje y de células granulares, así como la reducción del espesor de las capas de Purkinje y granular interna de la corteza del cerebelo en ratones neonatos.

PALABRAS CLAVE: Diabetes gestacional; Cerebelo; Celulas Purkinje; Células granulares; Rata.

\section{REFERENCES}

Ahmadpour, S. H. \& Haghir, H. Diabetes mellitus type 1 induces dark neuron formation in the dentate gyrus: a study by Gallyas' method and transmission electron microscopy. Rom. J. Morphol. Embryol., 52(2):575-9, 2011.
Anitha, M.; Gondha, C.; Sutliff, R.; Parsadanian, A.; Mwangi, S.; Sitaraman, S. V. \& Srinivasan, S. GDNF rescues hyperglycemiainduced diabetic enteric neuropathy through activation of the PI3K/ Akt pathway. J. Clin. Invest., 116(2):344-56, 2006. 
Arroba, A. I.; Frago, L. M.; Argente, J. \& Chowen, J. A. Activation of caspase 8 in the pituitaries of streptozotocin-induced diabetic rats: implication in increased apoptosis of lactotrophs. Endocrinology, 146(10):4417-24, 2005.

Beauquis, J.; Roig, P.; Homo-Delarche, F.; De Nicola, A. \& Saravia, F. Reduced hippocampal neurogenesis and number of hilar neurones in streptozotocin-induced diabetic mice: reversion by antidepressant treatment. Eur. J. Neurosci., 23(6):1539-46, 2006.

Biessels, G. J.; van der Heide, L. P. V.; Kamal, A.; Bleys, R. L. \& Gispen, W. H. Ageing and diabetes: implications for brain function. Eur. J. Pharmacol., 441(1-2):1-14, 2002.

Candy, S. M. \& Szatkowski, M. S. Neuronal excitability and conduction velocity changes in hippocampal slices from streptozotocin-treated diabetic rats. Brain Res., 863(1-2):298-301, 2000 .

DeBoer, T.; Wewerka, S.; Bauer, P. J.; Georgieff, M. K. \& Nelson, C. A. Explicit memory performance in infants of diabetic mothers at 1 year of age. Dev. Med. Child Neurol., 47(8):525-31, 2005.

Gardoni, F.; Kamal, A.; Bellone, C.; Biessels, G. J.; Ramakers, G. M. J.; Cattabeni, F.; Gispen, W. H. \& Di Luca, M. Effects of streptozotocin-diabetes on the hippocampal NMDA receptor complex in rats. J. Neurochem., 80(3):438-47, 2002.

Golalipour, M. J.; Kafshgiri, S. K. \& Ghafari, S. Gestational diabetes induced neuronal loss in CA1 and CA3 subfields of rat hippocampus in early postnatal life. Folia Morphol. (Warsz), 71(2):71-7, 2012.

Grillo, C. A.; Piroli, G. G.; Wood, G. E.; Rezinkov, L. R.; McEwen, B. S. \& Reagan, L. P. Immunocytochemical analysis of synaptic proteins provides new insights into diabetes-mediated plasticity in the rat hippocampus. Neuroscience, 136(2):477-86, 2005.

Hawkins, C. L. \& Davies, M. J. Generation and propagation of radical reactions on proteins. Biochim. Biophys. Acta, 1504(2-3):196219, 2001.

Hernández-Fonseca, J. P.; Rincón, J.; Pedreañez, A.; Viera, N.; Arcaya, J. L. Carrizo, E. \& Mosquera, J. Structural and ultrastructural analysis of cerebral cortex, cerebellum, and hypothalamus from diabetic rats. Exp. Diabetes Res., 2009:329632, 2009.

Jackson-Guilford, J.; Leander, J. D. \& Nisenbaum, L. K. The effect of streptozotocin-induced diabetes on cell proliferation in the rat dentate gyrus. Neurosci. Lett., 293(2):91-4, 2000.

Kamal, A.; Biessels, G. J.; Urban, I. J. \& Gispen, W. H. Hippocampal synaptic plasticity in streptozotocin-diabetic rats: impairment of long-term potentiation and facilitation of long-term depression. Neuroscience, 90(3):737-45, 1999.

Khaksar, Z.; Jelodar, G. \& Hematian, H. Effect of maternal diabetes on cerebellum histomorphometry in neonatal rats. J. Shahid Sadoughi Univ. Med. Sci. Health Services, 18(1):56-63, 2010.

Klein, J. P. \& Waxman, S. G. The brain in diabetes: molecular changes in neurons and their implications for end-organ damage. Lancet Neurol., 2(9):548-54, 2003.

Lebed, Y. V.; Orlovsky, M. A.; Nikonenko, A. G.; Ushakova, G. A. \& Skibo, G. G. Early reaction of astroglial cells in rat hippocampus to streptozotocin-induced diabetes. Neurosci. Lett., 444(2):181$5,2008$.

Li, Z. G.; Zhang, W.; Grunberger, G. \& Sima, A. A. Hippocampal neuronal apoptosis in type 1 diabetes. Brain Res., 946(2):22131, 2002.

Min, Y.; Lowy, C.; Ghebremeskel, K.; Thomas, B.; Offley-Shore, B. \& Crawford, M. Unfavorable effect of type 1 and type 2 diabetes on maternal and fetal essential fatty acid status: a potential marker of fetal insulin resistance. Am. J. Clin. Nutr., 82(6):1162-8, 2005.

Nelson, C. A.; Wewerka, S.; Thomas, K. M.; Tribby-Walbridge, S.; deRegnier, R. \& Georgieff, M. Neurocognitive sequelae of infants of diabetic mothers. Behav. Neurosci., 114(5):950-6, 2000.

Okouchi, M.; Okayama, N. \& Aw, T. Y. Differential susceptibility of naive and differentiated PC-12 cells to methylglyoxal-induced apoptosis: influence of cellular redox. Curr. Neurovasc. Res., 2(1):13-22, 2005

Reagan, L. P. \& McEwen, B. S. Diabetes, but not stress, reduces neuronal nitric oxide synthase expression in rat hippocampus: implications for hippocampal synaptic plasticity. Neuroreport, 13(14):1801-4, 2002.

Saravia, F. E.; Revsin, Y.; Gonzalez Deniselle, M. C.; Gonzalez, S L.; Roig, P.; Lima, A.; Homo-Delarche, F. \& De Nicola, A. F. Increased astrocyte reactivity in the hippocampus of murine models of type 1 diabetes: the nonobese diabetic (NOD) and streptozotocin-treated mice. Brain Res., 957(2):345-53, 2002.

Schoenle, E. J.; Schoenle, D.; Molinari, L. \& Largo, R. H. Impaired intellectual development in children with Type I diabetes: association with $\mathrm{HbA}(1 \mathrm{c})$, age at diagnosis and sex. Diabetologia, 45(1):108-14, 2002

Siddappa, A. M.; Georgieff, M. K.; Wewerka, S.; Worwa, C.; Nelson, C. A. \& Deregnier, R. A. Iron deficiency alters auditory recognition memory in newborn infants of diabetic mothers. Pediatr. Res., 55(6):1034-41, 2004.

\section{Correspondence to:}

Dr. Mohammad Jafar Golalipour

Gorgan Congenital Malformations Research Center

Department of Anatomical Sciences,

Golestan University of Medical Sciences

P.O. Box: 49175-1141, Gorgan

IRAN

Email: mjgolalipour@yahoo.com

Received: 27-08-2013

Accepted: 06-02-2014 